\title{
The Teaching of Civic Education in Zambian Secondary Schools as a Strategy for Effective Political Participation
}

\author{
Davy Mainde ${ }^{1}$, Daniel Katongo Chola ${ }^{2}$ \\ ${ }^{1}$ The University of Zambia \\ ${ }^{2}$ Mulungushi University
}

\begin{abstract}
The core focus of this study was to investigate the teaching of Civic Education in Zambian secondary schools and how it serves as a strategy for effective political participation in the community. This study was used a qualitative case study. Twenty (20) professional teachers in Civic Education and ThirtyFive (35) learners in Civic Education classes from Five(05) selected secondary schools in Lusaka district of Lusaka province were purposively nominated through homogenous sampling. One - to - one interview was used to collect information from teachers while focus group discussion was used to collected data from learners in Civic Education classes. The study established that the teaching of Civic Education in schools is positively serving a role of training learners for effective political participation as it provide them with knowledge on governance issues. It was also established that Civic Education prepare learners for effective leadership and critical thinking which are key to political participation. Further, the study established that learners are prepared for the way of life and political tolerance as they effectively participate in political affairs of their community. It was recommended that Schools should strengthen local Continuous Professional Development (CPD); the government of the republic of Zambia to come up with a clear policy that will arouse the interest of the young people through the teaching of Civic Education to effectively participate in political activities of their community while still in school; and the Ministry of General Education to constantly call for educational conferences to sensitise Civic Education teachers on the need to prepare learners for effective political participation as outline in the 2013 Zambia education curriculum framework.
\end{abstract}

Key Terms: Civic Education, Political Participation, Civic Knowledge, Civic Skills and Civic Dispositions.

\section{INTRODUCTION}

$\mathrm{C}$ itizens of any given community are required to take part in its operations either directly or indirectly. This has various dimensions which includes; economic, political or community participation. Oakley and Marsden (1984) look at participation as a concept that is closely linked to rural development. Participatory citizenship means becoming actively involved in building a better society. Thus, Mukisa (2009) relate citizen involvement to a bottom-up process of development. Additionally, Yezi (2013) views political participation as consisting of those legal activities by private citizens that are more or less directly aimed at influencing the selection of government personnel and/or the actions they take. Political participation can be seen when citizens get involved in choosing of their representatives through voting.

Following the enactment of the Mvunga Constitution and the reintroduction of multi-party participatory democracy in 1991, there has been a number of efforts to reinvigorate citizens' interest in political participation in Zambia. For instance, the Zambia Civic Education Association (ZCEA) was formed in 1993 to empower the Zambian citizenry in coping with the new democratic dispensations (Katongo, 2013), which led to the reintroduction of teaching of Civic Education in 2003 which was banned in 1978 at the senior secondary school level (Muleya, 2015), to act as a link between junior secondary school civics and the time when one graduates from tertiary education (Niemi \& Junn, 1998). The course was to impart into learners skills, knowledge and virtues needed for effective political participation in the community.Since then, the teaching of Civic Education at the senior secondary school has impacted the community through its civic knowledge, civic skills and civic values which are key education determinant in every citizen maturity. Topics such as elections, rights and constitution in Civic Education (Muntengwa, 2020) are a key in arousing interests of pupils when they become adults if taught through appropriate strategies. It is against this background that this study was conducted to investigate the teaching of Civic Education in Zambian secondary schools and how it serves as a strategy for effective political participation in Lusaka district.

\section{Problem Statement}

The democratic goals of education are; liberty (which entails knowledge), opportunity (which necessitate skills) and mutual respect (which concern dispositions) among people (Sardoc, 2018). Citizens ought to know when and how to exercise their liberties, to put into appropriate practices knowledge learnt and to have self-conviction to actively take part in public decision making processes. Eurydice Report (2017) provides the first step towards understanding what citizenship education is, as to understand its functions, which is none other than bridging the gap between the individual and the community. This gap can be addressed if citizens become informed, active and engaged in political, social, and other related issues of life through provision of relevant education 
(ACARA, 2012; Muleya, 2019a). In simplicity, the teaching of Civic Education globally should provide learners with knowledge, impart skills and inculcate good moral values to learners which will arouse their interest to actively take part in political affairs of their community.

However, it seems likethe teaching of Civic Education in Zambian secondary schools has not echoed more on preparing young people for effective political participation due to high voter apathy the country has in the recent past recorded especially among the young people of 20 to 24 years of age. This is despitecivic knowledge, civic skills and civic disposition which can help prepare them for effective political participation in their community. For instance, there were 5, 223,316 registered voters against the population of 13,718 , 722 in 2011; while 6, 698, 372 and only 3, 781, 505 voted against the population of 15, 473, 905 in 2015 (USAID, 2011; European Union, 2016; CSO, 2016; Carter Center, 2016). The youths between 15 and 25 years make the majority of the population of Zambia. However, the United Nations (2016) observed that the youths between ages 18 and 24 were below the projected eligible voter population while the European Union (2016) identified the wider gap of youths as registered voters which is 39.04 percent lower than projected eligible voters. The reasons for this apparent underrepresentation of youth voters however are unclear. It is against this background that this study was conducted to investigate the teaching of Civic Education in schools and how it is serving as a strategy for effective political participation.

\section{Purpose of the Study}

The main focus of this study was to investigate the teaching of Civic Education in Zambian secondary schools and how it serves as a strategy for effective political participation in the community.

\section{Theoretical Framework}

The theory which guided this study was the 'renaissance philosophy' of Machiavelli. Machiavelli was one of the Renaissance writers who did most of his work to shape republican ideas and to whom contemporary republican writers look up-to, to inform their own understandings of freedom (Maynor, 2003). His way of understanding about freedom and individual versus societal rights has attracted a number of researchers to echo in conquering to this idea.

Machiavelli's support for citizen participation within the political community would be considered extremely restricted in contemporary terms. However, such participation would be for many generally a matter of military service, and a commitment to serving the common good more often than active involvement in decision- making (Honohan, 2002). This can be achieved when strategic limitations are placed on the rulers so that competing interests are balanced and developed, and domination by particular factions avoided. To this effect, Skinner (1997) advocates for regular, free and fair elections as a way of expressing citizen participation in democratic society. Individual participation should not be aligned to only one certain group of people; instead citizens ought to participate freely in the politics of their community. In the setup of the political community, renaissance theory has a positive potential in the existence of competing interests and social factions, albeit mediated by laws and the constitution.

In addition, Machiavelli's renaissance theory work on the principles of self-government and participation in civic life is of greater importance accompanied with the incorporation of community institutions and laws. According to Held (1996), the basis of liberty may also bring conflict and disagreement through which citizens can promote and defend their interests. However, such tensions exist as necessary features of a republican state. It is from this point of view that citizen needs Civic Education to understand the context of shared membership of a political community as they devote time in participation.

Renaissance theory is relevant to the teaching of Civic Education as a strategy for effective political participation in the community as it provides room for individual participation in the activities of the community. It is only a civically minded person who can see this participation as his or her individual right if applied in a rightful manner. Through the teaching of Civic Education, graduates will be able to effectively participate in the political affairs through expression of their views and contesting for any public office. Such participation will be based on the welfare of the common good of the society in which such individuals affiliate themselves to. This theory will drive us to issues of liberty and freedom of individual and to the extent in which such privileges should be enjoyed by an individual.

\section{RELATED LITERATURE TO THE STUDY}

\section{Definition of Civic Education}

The study of Civic Education also known as Citizenship Education has come with various explanations on what it is constituted of. Scholars from diverse study orientations have different understanding on what Civic Education or Citizenship Education is. The question of defining Civic Education remains contentious, because of the broad ranging definitions and yet beyond these very broad definitions remains a huge range of competing and even contested definitions in the existing and new literature (Kuhn, 2006, Tovmasyan \& Thoma, 2008; Eurydice Report, 2017; Muleya, 2015; 2018; 2019). Civic Education is being increasingly reframed through different points that have emerged as key arenas in which the formal rights and duties of citizens are understood, expressed, and enacted on a daily basis. This subject is dynamic in terms of its definition, making it difficult to have a universal working definition due to changing and geographical needs of the community. Also, the way Civic Education was defined during the $20^{\text {th }}$ century may not be the same as emerging definitions in the $21^{\text {st }}$ century due to a number of innovations and challenges which the community faces at these different eons. Further, the way 
citizens in developed countries participate in decision making of their community, differs from the way citizens in developing countries participate. Therefore, time space and the environment in which one lives in is the key to understanding the meaning of Civic Education.

The study by Branson and Quigley (1998) called Civic Education in a democracy as education in self-government. In this kind of government, citizens are actively involved, not just passively accepting the dictums or acquiesce to the demands of others, instead they have a say in decision making of the community. It operates to instil individuals with governance principles, ethics, an understanding of how democratic institutions function in relation to citizen's rights and responsibilities to engage in the political system. Citizen participation in a democratic society must be based on informed, critical reflection, and on the understanding and acceptance of the rights and responsibilities that go with that membership. Therefore, Citizenship Education sharpens critical thinking capacities of young people which is important in the analysis of political, social, and other issues, as well as preparing them for their roles and responsibilities and for the challenges and uncertainties of life through provision of relevant education (Muleya, 2019).

As a school subject of study, Civic Education is supposed to provide young citizens with conceptions of citizenship, its rights and duties, governance and participation opportunities in a broad sense. It infers on making learners critical thinkers and active participants in democratic activities of their community. For this reason, the teachers for Civic Education must incorporate learning strategies which will promote effective political participation of citizens in the community.

According to Vasiljevic (2009), Civic Education is a way of learning for effective participation in a democratic and development processes. An Australian report on education curriculum indicate that, Civics and Citizenship Education provides opportunities to young people to become active and informed citizens in global contexts (ACARA, 2012). It is the field of study where learners acquire such skills which help them become active and informed members in their country and beyond. It is true that the learning of Civic Education results to empowerment of learners to become actively involved citizens in governance. Students of Civic Education should see it their responsibilities to actively engage themselves in public affairs. Thus, Satu (2007) proposed education which promotes recipients' understanding of the political system, their own interests, and options to contribute to government or citizens' rights and obligations. Therefore, Civic Education is the process of educating society through transferring the principles and rules of democracy, human rights and freedoms into open or closed goals in the education programmes (Şanlı and Mehmet, 2015). It involves exposing students to central and political traditions of the nation and teaching them moral sentiments in their respective community. Kerry's (2012) study established that Civic Education is primarily about understanding the political processes that regulate the daily lives of individuals in any society. It is important to know who one's political representatives are, but it is argued that as a more personal type of civic knowledge, knowing one's rights is the first step or a prerequisite for participation. This conceptualisation of Civic Education gives a platform for learning one's rights before engaging into participation. Therefore, Civic Education programs offered at any level must incorporate the process which will enable learners to start engaging themselves in influencing government decision as well as being involved through such allocated representation in decision making of their country.

Civic Education should not only operate to instil into learners all the democratic ideals, it must also provide the learning process on how such ideals are acquired and more emphasise must be placed on active participation in democratic governance in which this study undertook. The educators together with leaners of Civic Education must be advocators of social change with emphasis on inclusive citizen participation in democratic governance. Piñgul's (2015) study in Philippine pinpointed that Civic education is a basis for the formation of civic knowledge, skills, and dispositions for effective democratic participation. It is a carrier of these triple strands of education which needs to be incorporated for effective political participation.

\section{Key Principles of Civic Education}

\section{Civic Knowledge}

Civic knowledge refers to citizens' understanding of the workings of the political system and of their own political and civic rights and responsibilities which every individual in democratic society is entitled to. Citizens are supposed to have civic knowledgeable which involves the basic institutions and procedures of government, knowledge of the Constitution and Bill of Rights. Where one claim to have rights, there is also need for one's duties and responsibilities in reciprocity. Civic knowledge is concerned with the content or what citizens ought to know (Branson \&Quigely, 1998). In Owen (2015), a strong knowledge base facilitates individuals' development of political attitudes that are predicated on more than just emotion, and fosters comprehension of how their own interests fit into a complex political system. Thus, Lind (2019:3) argued that, "suffrage without schooling produces mobocracy, not democracy". In this way, political (civic) knowledge is directly related to participation, because those who have acquired it tend to be more politically efficacious in public matters.

\section{Civic Skills}

Civic skills refer to citizens' ability to analyse, evaluate, take and defend positions on public issues, and to use their knowledge to participate in civic and political processes in the community. Citizen participation in a democratic society must be based on informed, critical reflection, and on the understanding and acceptance of the rights and responsibilities 
that go with that membership (Branson \&Quigely, 1998) as Civic Education instil them abilities to make use of their own reasoning without directions from another person (Hinde, 2008). Lind (2019) opined that, it calls for the ability of every individual to solve the problems and conflicts that inevitably arise when orienting personal behaviour on moral principles, without recourse to violence, deceit or subjection to others, to whom the burden of responsibility is transferred. Civic education through civic skills engraved in it exists to make individual as source of peaceful solution providers in times when the community is in need.

\section{Civic Values}

Values are principles and fundamental convictions which act as justifications for activity in the public domain and as general guides to private behaviour. Muntengwa (2020), and Halstead and Pike (2006) provide us with features connected to values as; believe and practise justice, communal cooperation, freedom, security, responsibilities, honest and courtesy, sincere and have an independent mind and ensure that one does not interfere with the freedoms of others and vice versa. These are a key outcomes the community look up to every citizen who has studied Civic Education in relation to community participation.

In relation to civic values, Pingul (2015) brings out civic attitudes which refer to dispositions toward behaviours and practices involving civic and political participation, and democratic citizenship. Branson and Quigley (1998) uses civic disposition which refer to the citizen traits necessary for a democracy. There are two traits which are; traits of private character (thus according to Haniza (2014) include; moral responsibility, self-discipline, and respect for the worth and human dignity of every individual) and traits of public character (such as public spiritedness, civility, respect for the rule of law, critical mindedness, and willingness to listen and negotiate (Branson \& Quigley, 1998)). Civic Education is based on different positions whose focus though is meant to bring in the learners the kind of attitudes, dispositions, virtues and values that are required in building up strong and transformed communities (Muleya, 2015). Responsible citizens espouse civic values such as life, liberty, pursuit of happiness, equality, truth and promotion of the common good.

\section{METHODOLOGY AND DESIGN}

This study used qualitative research methodology which according to Garson (2002: 137) "strive for in-depth understanding of subjects through such techniques as participant observation or narrative analysis". According to Neuman (2004: 88), "qualitative researchers use a language of cases and contexts, examine social processin their social context, and look at interpretations or the creation of meaning in specific settings". This design enables scholars to look at social life from multiple points of view and explain how people construct identities. In this instance, a qualitative research was appropriate as teachers of Civic Education in selected secondary schools in Lusaka district of Lusaka province brought out multiple views in the social context on how the teaching of Civic Education prepare learners for effective political participation in the community.

The study used a descriptive case study research design, which is the detailed and intensive analysis of a single case concerned with the complexity and particular nature of that case in question (Scott and Deirdre, 2009). Further,Komb and Tromp (2006) describe case study as that research design whichbrings about deeper insights and better understanding of the problems faced by students. This design was appropriate to the study as it brought about in-depth views of all participants on how the teaching of Civic Education in secondary schools in Zambia facilitate as a strategy for effective political participation in the community.

\section{Target Population}

Kombo and Tromp (2006) define population as a group of individuals, objects or items from which the samples are taken for measurement. This study targetedtrained Civic Education teachers and pupils in Civic Education classes in the selected secondary schools in Lusaka district of Lusaka province whose focus was tocollect their views on the teaching of Civic Education and how it promote effective political participation in the community.

\section{Sample}

Kothari (2004: 55) describe sample as the,"list of respondents selected as representative of the total population in order to produce a miniature cross-section". It is a small proportion of the population which has been selected for the purpose of collecting views which can be generated as representation of the main population. In this study, 55 respondents were purposively selected through homogeneity sampling out of which Thirty-Five (35) were learners in Civic Education classes andTwenty (20)were trained teachers in Civic Education to collect their views on the teaching of Civic Education and how it is serving as a strategy for effective political participation in the community.

\section{Data Collection Techniques}

Data collection according to Kombo and Tromp (2006) is defined as the gathering of specific information aimed at providing or refuting some facts. There are two types of data sources namely; secondary and primary data which were used in this study on the value of Civic Education in relation to learners' interest on political participation.

Ranjit (2005) define secondary sources of data as those which have already been collected and analysed by someone else. Examples of secondary data include; news bulletins, magazines, newspapers, documentaries, advertising, the Internet, books and many others (Walliman, 2011). In this study, recent journal articles from global and continental perspective, academic books and internet sites whose contents are in line with Civic Education and political participation were reviewed. On the other hand, primary source of data is 
when collecting the information direct from the respondents through interviews or questionnaires (Ranjit, 2005). It is the data that has been observed, experienced or recorded close to the event for the purpose of getting the truth. The views from teachers of Civic Education were collected using one-on-one interviews while group focus discussion was used for pupils.

\section{Data Analysis}

Data analysis refers to examining, categorising, tabulating, and displaying and verifying of information collected in the field (Yin, 2003) in order to make sense of vast amounts of information, often from different sources. This study used a thematic data analysiswhere themes are topics or major subjects that come up in discussions (Kombo and Tromp, 2006). Thematic data analysis compels the researcher to select wording of the theme in a way that accurately represents the meaning of the responses categorized under a theme.

The data from both one-on-one interviews and group focus discussions was collected, transcribed and coded into themes and sub-themes that emerged during data collection. This was done by carefully listening to the recorded conversations in order to interpret, reduce and code key responses into major and sub-themes in relation with the research purpose.

\section{Ethical Issues}

According to Akaranga and Makau (2016), ethics are a branch of philosophy that deals with the conduct of people and guides the standards of behaviour of people and relationships with each other. Fouka and Mantzorou (2011) discusses the importance of research ethics in our daily life as to protect the dignity of the subjects and publish well the information that is researched. Therefore, research ethics can be said to be a correct behaviours and procedures that are necessary and in line with the recommended legal and ethical conduct of the researcher. In this study, respondents' titles are used in place of their identity. Before conducting the interview, an informed consent was sought from the informants and the researcher guaranteed them with security of the information provided. Also, the main objective of gathering such information was made clear to the respondents. The recordings were used only by the researcher to provide validation through counter checking of written data to what the respondent said, hence not for public use.

\section{IV.FINDINGS AND DISCUSSION}

\section{Civic Education for Effective Political Participation}

The main purpose of this study was to examine how the teaching of Civic Education in Zambian schools serves as a strategy for effective political participation in the community. After interacting with teachers of Civic Education and learners in Civic Education cases, there are a number of themes which emerged in relation to the study rationale. It was established that the teaching of Civic Education in secondary schools provides learners with: knowledge about governance, enlightenment on human rights, leadership skills, making of critical decisions and political tolerance.

\section{Knowledge about Governance}

This study established that the teaching of Civic Education helps learners to acquire governance knowledge which is prerequisite to political participation. The learners are made aware of two types of governance systems which are democratic and dictatorship. One of the teachers of Civic Education said,

“... Through Civic Education, children know the difference between good and bad governance and also get engaged in providing checks and balances when they become adults".

In line with teachers' views on Civic Education and governance, Boakye-Agyei (2006) see this subject as embracing several contexts such as corporate governance, international governance, national governance and local governance. Leaners get acquitted with governance issues at different space of their community. They are aware which kind of governance is ideal for the community in order to see that particular society record the development of citizens' dream. Similarly, Jindal (2014) re-echoed the importance of Civic Education in relation to citizen participation in good governance which help eradicating poverty and promoting development. Development can thrive where citizens are freely and willing to participate in the public affairs without limitations from any individual entity. Hence, these privileges are only common in a democratic community. Without good governance, no amount of developmental schemes can bring improvement in the quality of life of the citizens. For this reason, Civic Education becomes imperative to helping learners make a preferable choice between cherishing democratic governance or despotic governance in relation to development.

Another worthy noting aspect that came out clearly during this expedition is preparation of learners with governance practices through the teaching of Civic Education. The common focus-group response from learners shows that,

“... Civic Education has been helping us to choose a best method torule people when our time comes. Because of Civic Education, we are able to choose our representatives in the school council just as it happens in the community where our parents choose their members of parliament to represent them in the national assembly".

The above view brings a very important approach in training learners in Civic Education for political participation. The establishment of school council in schools creates a conducive ground for learners to learn practices of good governance through election of their representatives. A similar study conducted in Ireland by Perry (2011) agrees with this study where school council or student council act as a group of pupils within a school elected by their peers to represent them and their views. The electoral processes used in choosing members of school council confirm the relevance of Civic 
Education in relation to preparing leaners for political participation in the community.

\section{Enlightenment for Human Rights}

The findings of this study recognised the importance of Civic Education in relation to promotion, protection and respect for human rights. Most of the respondents from teachers' and learners'categoriesacknowledged Civic Education as an instrument which helps the citizens to be conscious of theirrights and those of others. For instance, one of the teachers representing others asserted that,

“... the teaching of Civic Education has tremendous benefits of making learners aware of their rights as well as the rights of their fellows as they enjoy their own right as they participate in politics".

Essential values to a civilised society such as human rights, tolerance, and respect for persons or anti-racism which students learn in schools through the teaching of Civic Education provide an effective way for political participation in the community. This course of study indeed play a significant role in helping citizens realise their individual rights and liberties as well as their obligations to the state. For instance, Woleola (2017) contended that, in good governance, there are institutions which stipulates complete entrenchment of individual and group rights and unbiased observance of the laws which includes an independent judiciary as well as an impartial and incorruptible Police Force. The matter centres on the fact that on one hand there is the individual who has to pattern his life according to the rules and the state, on the other hand which has to ensure the due enforcement of the rules which promote and protect one's rights. Those who have studied Civic Education have better understanding and application of the rights and are also able to engage the authority whenever their rights are infringed.

One of the objectives of education is to raise awareness of human rights and social issues, spark debate and enable informed social dialogue (UN, 2007; Halstead \& Pike, 2006). Social dialogue is one of the ways in which citizen can participate in the affairs of their community. Through the teaching of Civic Education in secondary schools in Zambia, citizens will know and enforce their rights through active participation in the community. Further, Kotite (2012) brings out another approach in rating human rights to social institutions. He argued that, respect for human rights begins in the family and community and educational institutions can play a critical role in fostering a culture of understanding and respect for human rights. Similarly, Mainde's (2018) study infers that, at the secondary school level in Zambia, leaners are given knowledge on the characteristics of human rights as well as ways of enforcing them. Enforcing human rights entails applying what was learnt in class into practice (participation). It is in the teaching of Civic Education in schools where a citizen may get confidence to effectively participate in the community.
Through the teaching and learning of Civic Education, students are alert of their rights and whenever their freedoms are infringed, they are aware of institutions responsible for handing such matters. The UNICEF (2007) report gives us details on the child's right to education as enshrined in human rights treaties, including articles 28 and 29 of the Convention on the Right of a Child. A critical implication is the requirement for primary education to be compulsory, available and free to all and secondary education to be available and accessible to every child, with the provision of financial assistance when needed. In the same vain, article 12 of the convention provides the protection of children to express their views freely and member state are obliged to enforce this provision. This provision enables the children to freely express their views through laid down procedures in the school. Therefore, Civic Education has helped the pupils aware of such provisions and get aroused to effectively participate during their school days and beyond.

Jindal (2014) support these findings in which, citizen's right of liberty, life and pursuit of happiness can be secured only through rule of law which citizens can learn through Civic Education. Satu (2007) argued that education create an active citizens who during community meetings are free to discuss their rights, responsibilities, and topics of importance to the community. Further, Muleya (2015) describe an active citizen as one with a positive mind-set and willing to work towards changing the status quo in the community. The change of mind-sets and attitudes are key elements to social change and transformation of society. Thus, the teachings of Civic Education create an environment where every member of the community is actively involved in making his community a better place to live.

\section{For Leadership Skills}

It was found that the teaching of Civic Education at a senior secondary school empower learners with leadership skills which are necessary for effective political participation in the community. A number of teachers interviewed supported this viewpoint. Among them, one of Civic Education teachers argued that,

"Civic Education prepare learners for leadership skills and social responsibility which help them to participate at any level of the community they find themselves to be after secondary school... we teach them how to argue and stand for the common good of their community".

It is clear that the teaching of Civic Education prepare learners for future leadership and social responsibilities. This study is in line with the views of Kotite (2012) who see education as an instrument working with the youths, by harnessing and respecting their contribution as future leaders. With leadership skills, these children will take a leading role to participate in the political affairs of the community. Grindle (2008) pinpointed that, human beings would all be better off, if public life were conducted within institutions that were fair, judicious, transparent, accountable, participatory, responsive, 
well-managed, and efficient. Such ideals can only be present in the community if leaders of such particulars entities strive to show leadership skills above every member of the community as provided in the teaching of Civic Education. Civic Education helps children to acquire communication skills which stimulate them to voice out through established institutions when things are not well in the community. The procedures they learn at school empower them to be responsible persons in the community they find themselves into after their secondary school.

Good leaders will always accommodate diverge views of others in the community. They will also encourage other members of the community to take part in the affairs of their community in providing solutions to the problems affecting them. Thus, Finkel (2000) contended that, more recent political participation research provides even more optimism that Civic Education have a significant impact on the individual's level of engagement with the political system. A well informed citizen will know that he or she is a leader at whatever level he or she finds him or herself in the community.

\section{Make them Critical Thinkers}

The teaching of Civic Education in schools promote critical thinking among learners. The views of teachers and learners agrees as they observed that those who have studied Civic Education during their school time seem to have unique skills in analysing issues in the community. They do not just follow the majority in making decisions during polls even when they are influenced by their friends, instead they critically analyse the relevance of every promise contesters present in relation to the needs of the society. One of the long serving teacher presented his observations as,

"Through Civic Education, people are able to argue out and make informed decisions especially during democratic campaigns where a different candidate approaches one society to sale out their manifestoes. All these were not there before Civic Education was introduced as a subject to be taught at the senior secondary school level in Zambia".

The above reflection can be well placed during the period of one party participatory democracy (1973-1991) as no person was allowed to freely decide a political group as only the ruling party existed. The advent of democracy and organisations to enlighten citizens on democracy added value in the community resulting to the teaching of Civic Education at senior secondary school in Zambia. Civic Education provided people with universal suffrage, which is one of the filaments for citizen participation in political affairs. Thus, Lind (2019:3) argued that, "suffrage without schooling produces mobocracy, not democracy".

Similarly, response from learners confirm how it is difficult to manipulate a Civic Education graduate. One of the panellist argued that,
"Sir, it is difficult to convince a pupil for Civic Education to what you want him or her to do without their concern. We are made to think, and not to accept anything that comes on our way. If all Zambians had this knowledge, we would have not been cheated by politicians who come to seek for votes and thereafter, they leave us suffering".

The findings of this study seem in line with the Ministry of Education (1996) document which promote the teaching that help learners develop desirable intellectual skills and qualities such as reflective reasoning, logical thinking ability and ability to concentrate on the target. Citizens are empowered with skills to analyse the policies and actions of those in public offices as well as those seeking these offices. The major emphasis is in the teaching of Civic Education for empowering citizens to provide accountability to their leaders. Since the doctrine of accountability in good governance emphasizes all actors, particularly those in government, business, voluntary agencies, civil-societies, among others are to be made answerable to the society (Rotberg, 2004; Rothstein and Teorell, 2008 in Woleola, 2017), citizens are provided with such privilege to participate in decision of their community effectively. When learners learn Civic Education, they will know that the only place to find answers concerning affairs of their community is from their elected leaders without intimidation.

\section{Political Tolerance}

The study established that Civic Education encourages political tolerance in the community. It helps citizens have political tolerance towards other members of the community who may have different views to theirs as they participate politically. Political tolerance simply means that people with different political opinion must be able to freely express themselves and their opinions should be respected. One should not be forced to accept another person's opinion. Political violence against people who support different political parties or candidates should not be tolerated.

The study revealed that learners start the practice of political tolerance while still in the secondary school through classroom interactions guided by the teachers. Civic Education helps them to tolerate each other's view even when do not agree with another classmate on argument he or she is trying to stress. This is evidenced by a team of learners who emphasised that,

“.... those of us doing Civic Education do not hurt our friends who have opposite view to ours when they are making contribution. We just compete with them and at the end of the time; we remain as one united class with different views".

The researcher is therefore convinced that this course of study has a potential to unite a heterogeneous community through transforming what happens in classroom into real community practices. Thus, Collier (2000) observed that, culture identity is a source of conflict where warring groups claim power over each other through their cultural practices. However, through 
the teaching of Civic Education, such incompatibility cannot be found as every member is aware of his or her responsibility. Therefore, the teaching of Civic Education in school has the potential to train the citizens to effectively participate in political affairs pf their community.

\section{CONCLUSION}

This study was set to investigate the teaching of Civic Education in Zambian secondary schools and how it serves as a strategy for effective political participation. The study employed a case study to collect data from teachers and pupils of Civic Education according to the above study focus. It was established that the teaching of Civic Education in secondary schools has positive impact on effective political participation. Civic Education provides learners with knowledge on governance and human rights. The teaching of Civic Education in schools equips learners with leadership and critical thinking skills as they endeavour to participate in the community. As they participate, the teachings of Civic Education in schools mould learners to good citizen status as they are trained to tolerate others as they dedicate their time for political participation. This study has a significance influence as it arouse interest of learners as they become adult to effectively participate in political system of their country.

\section{RECOMMENDATIONS}

In view of the study findings, the following are important recommendations made;

i. Schools to strengthen local Continuous Professional Development (CPD) activities such as Lesson Study Circle, Cluster Meetings and Professional Subject Associations Workshops to reinvigorate Civic Education teacher with new knowledge and skills.

ii. The government of the Republic of Zambia to come up with a clear policy that will arouse the interest of the young people through the teaching of Civic Education to effectively participate in political activities of their community while still in school.

iii. The Ministry of General Education to constantly call for educational conferences to sensitise Civic Education teachers on the need to prepare learners for effective political participation as outline in the 2013 Zambia education curriculum framework.

\section{REFERENCES}

[1] Akaranga, S. I. and Makau, B. K. (2016). Ethical Considerations and their Applications to Research: a Case of the University of Nairobi. Journal of Educational Policy and Entrepreneurial Research. 3(12), pp 1-9.

[2] Boakye-Agyei K. (2006). Fostering Civic Engagement: Stakeholder Participation in Rural Projects in Ghana. A dissertation submitted in partial fulfilment of the requirements for the degree of Doctor of Philosophy at George Mason University.

[3] Branson, M. S. and Quigley, C. N. (1998). The Role of Civic Education. New York.

[4] Eurydice Report (2017). Citizenship Education at School in Europe. Brussels.

[5] Finkel, S. E. (2003). "Can Democracy Be Taught", Journal of Democracy. 14 (4), pp. 34-38.
[6] Fouka G. \&Mantzorou M. (2011). What are the Major Ethical Issues in Conducting Research? Is there a Conflict between the Research Ethics and the Nature of Nursing?Health Science Journal. 5 (1), pp. 3-14.

[7] Garson, G. D. (2002). Guide to Writing Empirical Papers, Theses and Dissertations. New York: Marcel Dekker, Inc.

[8] Grindle, M (2010). Good Governance: The Inflation of an Idea, Faculty Research Working Paper Series. Harvard University.

[9] Halstead J. M and Pike, M. A. (2006). Citizenship and Moral Education Values in Action.London: Routledge.

[10] Haniza, M. (2014).Civics and Citizenship Education in Malaysia: The Voice of Micro Policy Enactors. A Thesis Submitted in Fulfilment of the Requirements for the Degree of Doctor of Philosophy of Cardiff University.

[11] Hinde, R. E. (2008). Civic Education in the NCLB Era: the contested mission of elementary and middle schools. Journal of curriculum and instruction (JoCI). 2(1), pp. 74-86.

[12] Jindal, N. (2014).Good Governance: Needs and Challenges. International Journal of Scientific \& Engineering Research. 5(5), pp. 113-116.

[13] Khalid, M. A., Alam, Md. M., and Said, J. (2016). Empirical Assessment of Good Governance in the Public Sector of Malaysia. Economics and Sociology. 9(4), pp. 289-304. DOI: 10.14254/2071-789X.2016/9-4/18.

[14] Mainde, D (2018). The Teaching of Civic Education in Zambian Schools: A Tool for Conflict Resolution in the Community. A Study of Selected Schools of Lusaka Province. A dissertation submitted to the University of Zambia in collaboration with Zimbabwe Open University in partial fulfilment of the requirements for the award of the degree in Masters Science in Peace, Leadership and Conflict Resolution. Lusaka.

[15] McCowan, T. (2009). Rethinking Citizenship Education: A Curriculum for Participatory Democracy. London: Continuum.

[16] MOESVTEE (2013). Zambia Education Curriculum Framework 2013. Lusaka: CDC.

[17] Muleya, G. (2015). The teaching of Civic Education in Zambia: An Examination of trends in the teaching of Civic Education in Schools. PhD dissertation: University of South Africa.

[18] Muleya, G. (2019). Curriculum Policy and Practice of Civic Education in Zambia: A Reflective Perspective, In A. Petersen et al. (eds.). The Palgrave Handbook of Citizenship and Education. https://doi/10.007/978-3-319-67905-153-1

[19] Muleya, G. (2019). Re-examining the Concept of Civic Education.Journal of Lexicography and Terminology. 2(2), pp. 2542.

[20] Muleya,G.(2018b). Civic Education Versus Citizenship Education? Where is the point of Convergence? Journal of Lexicography and Terminology. 2(1), pp 109- 130.

[21] Muntengwa,W., Namadula, B., Hamainza, V., Simwatachela, R., Kakana, F., Simui, F. and Muleya, G. (2020). Unearthing Disablers in the Cultivation of Civic Skills among Learners in Selected Secondary Schools in Lusaka District, Zambia. International Journal of Research and Innovation in Social Science (IJRISS). IV (IX), pp. 228-238.

[22] Neuman, W. L. (2004). Basics of Social Research: Qualitative and Quantitative Approach, ( ${ }^{\text {nd }}$ ed.) Boston: Pearson Education, Inc.

[23] Niemi, R. G., Richard, G. \&Junn, J. (1998). Civic EducationWhat Makes Students Learn. London: Yale University Press.

[24] Owen, D. (2015). High School Students' Acquisition of Civic Knowledge: The Impact of We the People. Georgetown University.

[25] Piñgul, F. S. (2015). Measuring the Impact of a Supplemental Civic Education Program on Students' Civic Attitude and Efficacy Beliefs.Journal of Education and Training Studies. 3(2), pp. 6169.

[26] Ranjit, K. (2005). Research Methodology-A Step-by-Step Guide for Beginners, $\left(2^{\text {nd }}\right.$ ed.). Singapore: Pearson Education.

[27] Şanl, Ö. and Mehmet, A. (2015). The Significance of Establishing Democratic Education Environment at Schools. International Journal on New Trends in Education and Their Implications. 5(2). www.ijonte.org 
[28] Satu, R. (2007). Empowering the Poor? Civic Education and Local Level Participation in Rural Tanzania and Zambia. A Dissertation Submitted in Partial Fulfillment of the Requirements for the Degree of Doctor of Philosophy in the College of Arts and Sciences. Georgia State University.

[29] Scott, W. V. and Deirdre, D. J. (2009). Research Methods for Everyday Life: Blending Qualitative and Quantitative Approaches. San Francisco: Jossey-Bass.

[30] Tovmasyan, T. and Thoma, T. M. (2008). The Impacts of Civic Education on Schools, Students and Community. New York: Caucasus Research Resource Centre.
[31] Vasiljevic, B. (2009).Civic Education as a Potential for Developing Civil Society and Democracy. Tromsø: University of Tromsø.

[32] Woleola, J. E. (2017).Good Governance Theory and the Quest for Good Governance in Nigeria.International Journal of Humanities and Social Science. 7(5), pp. 154-161.

[33] Yin, R. K. (2003). Case Study Research Design and Methods, $3^{\text {rd }}$ ed. London: Saga Publication, Inc. 